\title{
A NEW MICROCOCCUS, WITH A NOTE ON THE BACTERIOLOGY OF LYMPHADENOMA.
}

By John Hill Abray, M.D., M.R.C.P., Assistant Physician, Royal Infirmary; Senior Demonstrator of Pathology, University College, Liverpool.

From the Pathological Laboratory, University College, Liverpool.

\section{(Plate XXXI.)}

I HAVE lately had a case of lymphadenoma under my care, in which I have made a bacteriological examination of the blood during life. I have long felt that the ordinary method of obtaining blood for this purpose is unsatisfactory, and I adopted the following method, which was, I believe, first recommended by Sittmann. The skin of the forearm was sterilised by packing with a towel soaked in 1 to 1000 perchloride of mercury for two hours, and then the needle of a hypodermic syringe (sterilised by boiling for five minutes) was thrust into one of the superficial veins. In this way a fair quantity of blood can be obtained without causing more than momentary pain.

Plates were made in the usual manner. Fourteen colonies developed in a single plate, the majority being pure growths of Staphylococcus albus. In addition to these there were three colonies of an organism having the following characteristics

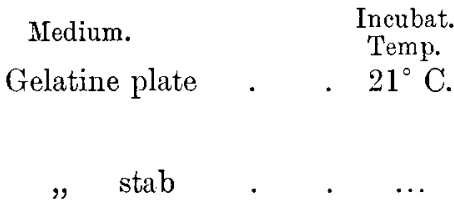
Agar plate . $\quad .37^{\circ} \mathrm{C}$
"stroke.
Potato

Milk . $\quad \cdot \quad \cdot \quad \cdot \quad \cdot$

Broth . . . . . .

Litmus agar . . . ...
Slow growth. Colony circular, surface finely granular, margin regular. Slow liquefaction.

Growth faster at surface than in depth. Slow liquefaction reaching wall of tube in six days.

Fairly rapid growth on surface, colony round, regular edges.

Growth fairly rapid, is slimy and resembles a streak of white paint.

Good growth. Culture raised, dark red, no staining of potato substance.

No coagulation.

Abundant growth; powdery sediment.

Medium turns red.

No gas formation. 
Microscopically the organism is a small micrococcus, aggregated in clumps. It stains well by the ordinary methods; it is not stained by Gram's method; it is non-motile. Inoculation experiments have given negative results. So far as I can ascertain, the organism isolated has not been described before.

Further examinations of the blood have failed to detect any organisms, and, taking into account the failure of the inoculations, it is evident that this organism has nothing to do with lymphadenoma. At the time it was present, the patient was undergoing a febrile attack, no doubt due to the Staphylococcus albus infection.

Before considering the question of the bacteriology of Hodgkin's disease, it is necessary to point out the confusion which exists with regard to the exact application of the term lymphadenoma. This is well shown in the list of names given by von Limbeck ( ${ }^{1}$ ) under the generic term-Pseudo-leukæmia : (Hodgkin's disease), Anæmia lymphatica (Wilks), cachexie sans leucémie (Bonfils), adenie (Trousseau), Anæmia splenica (Griesinger), malignes lympho-sareom (Langhans), malignes Lymphom (Billroth), desmoid Carcinom (R. Schulz).

It is, I believe, not yet possible to draw sharp lines between the conditions which are mustered under the title of pseudo-leukæmia, but it seems probable that it includes more than one disease.

Taking the condition from a general point of view, it has of late years been more and more frequently urged that it is of an infective nature on the score of (1) the anatomical structure of the enlarged glands and the deposits in the various organs; (2) the symptomatic features, anæmia, hæmorrhages, and so forth.

On looking up the literature, the investigations of the disease from the infective point of view have not been numerous. Klebs $\left({ }^{2}\right)$ states that Weigert found bacilli having the staining characteristics of tubercle bacilli in the enlarged mesenteric glands, and that he himself in one case found a short freely motile bacillus in the blood, both during life and post-mortem. Kelsch and Vaillard $\left(^{3}\right)$ in a case of "Tumeurs lymphadeniques multiples avec Leucémie," found once during life and in the organs after death a short non-motile bacillus, hardly longer than broad, staining readily with methylene-blue but not by Gram's method. It did not liquefy gelatine, and on potato at $35^{\circ} \mathrm{C}$. gave a moist shining yellowish-brown growth. Inoculations into guinea-pigs gave no results, but rabbits and white mice were killed in thirty-six hours. They do not claim specific properties for this organism.

Dreschfeld $\left(^{4}\right)$ has put on record a case of acute Hodgkin's disease, in which small bacilli were found in the kidney post-rnortem. Cultivations were not obtained. Traversa $\left(^{5}\right)$ has recorded a case of acute pseudo-leukæmia, in which streptococci were found in the blood during life, and Grossi $\left({ }^{6}\right)$ a similar case, in which the examination had a negative bacteriological result. Lannois and Groux $\left({ }^{7}\right)$ have recorded 
a case of acute pseudo-leukæmia in which Staphylococcus pyogenes aureus was found.

It may fairly be assumed that in my case and in those of Traversa, Lannois, and Groux, the organisms found were the result of a secondary infection; and in my own case it is interesting to note that, during the period of secondary infection, the glandular swellings diminished greatly in size, to again enlarge when the organisms disappeared from the blood. In Dreschfeld's case the organism was found only in the kidney, and moreover only after death, so that but little value can be attached to its presence. Kelsch and Vaillard claim no specific property for their organism.

In conclusion, the organism of lymphadenoma, if organism there be, has yet to be isolated, and the method of Sittmann would appear to afford the best means for its detection.

\section{BIBLIOGRAPHY.}

1. Von Limbeck, . . . . "Klin. Path. des Blutes," 2 te Aufl. S. 326.

2. Klebs, . . . . . . . "Allgemeine Pathologie."

3. Kelsch and Vaillard, . Ann. de l'Inst. Pasteur, Paris, 1890, tome iv. p. 276.

4. Dreschfeld, . . . . Brit. Med. Journ., London 1892, vol. i. p. 893.

5. Traversa, . . . . . Riforma med., Napoli, 1893, t. ix. p. 26.

6. Grossr,. . . . . . . Ibid., 1893, t. ix. p. 62.

7. Lannols and Groux, . . Lyon méd., 1890, No. 34.

\section{DESCRIPTION OF PLATE XXXI.}

Fig. 1.-Agar growth.

FIG. 2.-Potato growth. 